\title{
Investigation of the features of phase formation in the joint aluminothermic reduction of $\mathrm{ZrO}_{2}, \mathrm{Ta}_{2} \mathrm{O}_{5}, \mathrm{Nb}_{2} \mathrm{O}_{5}$
}

\author{
(C) Andrey S. Russkih, Sergey N. Agafonov, ${ }^{*}$ and Artem A. Ponomarenko ${ }^{+}$ \\ Institute of Metallurgy of the Ural Branch of the Russian Academy of Sciences. \\ Amundsen St., 101.Ekaterinburg, 620016.Russia.E-mail: russkih_a_s@mail.ru
}

\begin{abstract}
*Supervising author; ${ }^{+}$Corresponding author Keywords: physical chemistry, reduction, thermodynamics, oxides, phase formation, zirconium, tantalum, niobium, intermetallides.
\end{abstract}

Abstract
In this paper, we consider the advantage of using the metallothermic method for producing alloys, in contrast to traditional methods. Using the HSC Chemistry 6.1 software package, thermodynamic modeling was performed. The possibility of obtaining intermetallic compounds by the joint aluminothermic reduction of $\mathrm{Zr}, \mathrm{Ta}, \mathrm{Nb}$ oxides is shown. The alloy was obtained by aluminothermic reduction of aluminum, zirconium, tantalum and niobium oxides in a resistance furnace, followed by grinding and powder size 40-100 microns. An experimental study of the sequence of phase formation and the boundaries of their existence was investigated using differential thermal analysis (DTA). The experiment was carried out on a STA 449 F3 Jupiter (NETZSCH) synchronous thermal analysis instrument in an argon flow GOST 10157-79 (the volume fraction of argon is at least $99.993 \%$ ), the flow rate of the gas used was $30 \mathrm{ml} / \mathrm{min}$. X-ray phase analysis (XRD) of the products (after DTA) was carried out on an XRD 7000 diffractometer (Shimadzu). By the relative intensity of the lines of the various phases, their quantitative ratio was estimated. The diffraction patterns were decoded using literature data, as well as the JCPDS (International Center for Diffraction Data) and ASTM (American Society for Testing and Materials) databases. According to the obtained XRD data, in the sample at temperatures of 954.5 and $1309.1{ }^{\circ} \mathrm{C}$, respectively, the formation of a solid solution $(\mathrm{Zr}, \mathrm{Nb}$, Ta) $\mathrm{Al}_{2}$ occurs, which is isostructural to the intermetallic $\mathrm{Al}_{3} \mathrm{Zr}$. In both cases, the concomitant $\mathrm{ZrAl}_{2}$ intermetallic compound is also formed. The performed study can serve as a scientific basis for the development of promising metallothermal technologies for the production of rare metal alloys.

\section{References}

[1] A.A. Ponomarenko, S.A. Krasikov, S.A. Ilynych, A.V. Dolmatov, and B.R. Gelchinski. Strength properties of Al-Ti-Ni-Mo coatings obtained by supersonic plasma spraying. Butlerov Communications. 2018. Vol.55. No.8. P.116-119. DOI: 10.37952/ROI-jbc-01/18-55-8-116

[2] N.I. Ilinykh, T.V. Kulikova, G.K. Moiseev. Composition and equilibrium characteristics of metallic melts of binary systems based on iron, nickel and aluminum. Yekaterinburg: Ural Branch of the Russian Academy of Sciences. 2006. P.236. (russian)

[3] N.A. Vatolin, G.K. Moiseev, B.G. Trusov. Thermodynamic modeling in high-temperature inorganic systems. Moscow: Metallurgy. 1994. P.352. (russian)

[4] A. Roine. Outokumpu HSC Chemistry for Windows. Chemical Reaction and Equilibrium Software with Extensive Thermochemical Database. Pori: Outokumpu Research OY. 2006. P.448.

[5] R.J. Kematick, H.F. Franzen. Thermodynamic study of the zirconium-aluminum system. Journal of Solid State Chemistry. 1984. Vol.54. P.226-234.

[6] S.N. Agafonov, S.A. Krasikov, A.A. Ponomarenko, L.A. Ovchinnikova. Phase formation during aluminothermic reduction of ZrO2. Inorganic materials. 2012. Vol.48. No.8. P.927. (russian)

[7] M. Hansen, K. Aderko. Structures of double alloys. Moscow: State scientific and technical publishing house of literature on Cher. and color. metallurgy. 1962. Vol.1. P.608. (russian)

[8] S.P. Alisova, P.B. Budberg, N.V. Ageev. State diagrams of metal systems. Moscow: VINITI. 1966. Vol.12. P.240. (russian)

[9] N.P. Lyakishev. State diagrams of binary metal systems. Moscow: Engineering. 1996. Vol.1. P.218. (russian)

[10] A.V. Larionov, V.M. Chumarev, L.Yu. Udoeva et al. Modeling of aluminothermic smelting of Al-Zr and Al-Zr-Mo-Sn alloys. Metals. 2013. No.5. P.3-9. (russian)

Kazan. The Republic of Tatarstan. Russia.

(C) Butlerov Communications. 2019. Vol.60. No.11. 
[11] S.R. Schmidtt, H.F. Franzen. Nthalpies of formation in the tantalum-sulfur and tantalum-aluminum systems. Journal of the less-common metals. 1986. Vol.116. P.78.

[12] M.P. Kuzmin, A.I. Begunov. Approximate calculations of the thermodynamic characteristics of aluminum-based intermetallic compounds. Vestnik ISTU. 2013. No.1. P.98-101. (russian)

[13] L.B. Vedmid, S.N. Agafonov, Yu.A. Avraamov, M.V. Ilinykh, A.G. Merkushev, Plotnikov M.S., A.F. Terlyga. Using the thermal analysis method for the modeling process of aluminothermic reduction of zirconium from oxides. Melts. 2017. No.4. P.289-293. (russian)

[14] E.M. Zhilina, S.N. Agafonov, A.S. Russkih, S.V. Zhidovinova, V.P. Chentsov, and S.A. Krasikov. Aluminium interaction with multicomponent oxide system consisting of zirconium, titanium, silicon, iron. Butlerov Communications. 2017. Vol.51. No.7. P.55-60. DOI: 10.37952/ROI-jbc-01/17-51-7-55 